circular and cluster arrangements of seismometers and with various methods of weighting the signals (signal/ noise power ratio, Tchebyscheff polynomials, etc.) in order to improve pulse recognition and measurement. Work on data analysers (chiefly for velocity and azimuth) is in progress. It might be added that seismological arrays are now in operation at Eskdalemuir, Scotland (United Kingdom Atomic Energy Authority), in Canada, in India, in Australia and in the United States.

\section{Action of Ammonium Salts on Concrete}

APART from ammonium sulphate, data on the action of ammonium salts on concrete are limited and, in some cases, conflicting. The problem has been investigated by Dr. F. M. Lea (Building Research Station), whose paper on "The Action of Ammonium Salts on Concrete" has recently been published (Magazine of Concrete Research, 22, 17; September 1965. Cement and Concrete Association, London, S.W.1). Dr. Lea studied the action of 5 per cent solutions of ammonium salts on a Portland, a Portland-pozzolana, and a high-alumina cement concrete. $\mathrm{He}$ found that ammonium chloride and nitrate solutions had a strong leaching potential, acting as dilute acids consequent on loss of ammonia by reaction with lime. Strengths of concrete cubes with all three cements fell by at least half in 4 years, without outward signs of deterioration. Examples are quoted of comparative compressive strengths (in $1 \mathrm{~b} . /$ in. $^{2}$ ) of 4 -in. cubes of $1: 2: 4$ concrete; in the case of Portland cement, storage in water for 1 year gave the figure 6,310 ; in 5 per cent ammonium nitrate 1-year storage reduced this to 4,340 ; after 4 years the figure was 2,310 ; a 60 per cent Portland cement and 40 per cent spent oil-shale pozzolana mix gave corresponding figures of $4,960,3,500$ and 2,440 ; cubes of high-alumina cement showed a similar trend with corresponding figures $9,340,7,180$ and 4,400 . Chemical analyses of some specimens tested show large reductions in the lime content of the cements.

In a further significant series of tests, to determine compressive strengths (in lb./in. ${ }^{2}$ ) of $50 \mathrm{~cm}^{2}$ cubes of $1: 2: 4$ concrete, the following results were obtained: for Portland cement stored in water for 1 year, 7,320; the same stored for 3.5 years, 8,420 . In 5 per cent ammonium nitrate, the corresponding figures were 4,525 and 3,050 . In 5 per cent ammonium chloride, the figures for 1-year and 3.5-year storage were 4,140 and 2,110 ; and in 5 per cent ammonium sulphate, stored for 1 year, the figure was 825. High-alumina cement revealed similar reductions under the same conditions: in water the figures were 9,830 and 9,730 (storage for 1 and 3.5 years, respectively); with 5 per cent ammonium nitrate the reduction was from 4,685 to 1,520 ; with 5 per cent ammonium chloride the reduction was from 7,810 to 5,720 ; but with 5 per cent ammonium sulphate, only 10,110 to 9,115 . (All the foregoing results are means of tests on four cubes.) Regarding the reaction of ammonium sulphate on Portland cement, the formation of calcium sulpho-aluminate producing expansion is dominant, and Dr. Lea attributes this to its solubility being lower than that of the nitro- or chloro-aluminates.

\section{Control of Tuberculosis}

International Work in Tuberculosis, 1949-1964, is the title of a reprint from the WHO Chronicle which reviews the tuberculosis programme of the World Health Organization (Pp. 32. Geneva: World Health Organization; London: H.M.S.O. 1965. 2 Sw. franes; $3 s .6 d . ; 0.60$ dollars). In 1948, the World Health Assembly decided to make tuberculosis control one of the priority programmes of the World Health Organization. Initially, there were two main aspects of the work of the World Health Organization: the demonstration of modern methods of tuberculosis control to developing countries and collaboration with the United Nations Children's Fund in mass BCG vaccination programmes. In 1959, the work took a new direction. Research into the epidemiology of tuberculosis assisted by the World Health Organization had shown that some of the conventional ideas about the disease were erroneous, and clinical research assisted by the World Health Organization had shown that domiciliary treatment of tuberculosis by drugs was as effective as, and cheaper than, institutional treatment. The experience of the World Health Organization with classical methods of control had shown that training and demonstration projects would not, by themselves, promote new programmes and that mass BCG programmes also had limitations. A new approach to the control of tuberculosis was therefore evolved, namely, the concept of the national tuberculosis programme adapted to the needs and resources of each country and planned by a national tuberculosis institute. The first of these institutes was opened in Bangalore in 1959, and the success of the programme developed there exceeded expectations. This concept is now being used to deal with the widely differing problems met with in countries now receiving help from the World Health Organization for tuberculosis control. Research has been, since 1949, an integral part of the tuberculosis control programme of the World Health Organization, and thirty-four national institutions in twenty-four countries are now taking part in this work. The activities range from the establishment of a standard tuberculin test to the development of cheap and effective standard chemotherapy. This publication contains seven sections on various aspects of control programmes and five sections on research and diagnostic procedures, epidemiology, immunization, chemotherapy and chemo-prophylaxis, and systems analysis.

\section{Effect of Experimental Haemorrhage on Haemoglobin Plasma Iron and Total Iron-binding Capacity in Dairy Calves}

WHEN K. C. BREMner, of the Division of Animal Health, and J. A. Ronald, of the Wheat Research Unit, C.S.I.R.O., withdrew blood samples of 10,20 and $30 \mathrm{ml} . / \mathrm{kg}$ body-weight from healthy dairy calves, the plasma total iron-binding capacity increased (Austral. J. Exp. Biol. and Med.Sci., 43, Part 5; October 1965). Plasma iron concentrations also increased significantly after bleeding at the two higher levels, but were unaffected by a blood loss of $10 \mathrm{ml} . / \mathrm{kg}$. Calves bled daily for 2 weeks at rates of 2,4 or $6 \mathrm{ml} . / \mathrm{kg} /$ day also had significantly increased plasma total iron-binding capacity. Blood losses of 2 or $4 \mathrm{ml}$. $/ \mathrm{kg}$ / day resulted in an elevation of plasma iron concentration. However, phlebotomies of $6 \mathrm{ml} . / \mathrm{kg} /$ day eventually caused a marked depression of plasma iron levels, but when the bleedings stopped, plasma iron concentrations increased to abnormally high values. It is suggested that the increased plasma iron levels were due to an increased absorption of dietary iron. Labile iron reserves in the experimental calves were estimated to lie within the range $1 \cdot 0-1 \cdot 4 \mathrm{~g}$, and were associated with liver concentrations of non-haem iron of about $30 \mu \mathrm{g} / \mathrm{g}$ wet liver. In calves, levels of non-haem iron in liver tissue of less than $20 \mu \mathrm{g} / \mathrm{g}$ appoar to be indicative of iron deficiency.

\section{Exchange Scheme between Britain and India for Younger Scientists}

DURING the past 2 years there has been in operation an exchange scheme designed to establish or maintain contact between British universities or research institutes and their counterparts in India through visits by younger scientists. The scheme, originally proposed by the (then) scientific adviser to the Indian High Commission in London, provides for six visits of between 6 weeks and 4 months duration by younger British scientists to India, 